\title{
Prevalence of Metabolic Syndrome and Affecting Factors among Individuals Aged 30 and over in Balçova District of İzmir
}

\author{
Ahmet Soysal $^{1}$, Hatice Şimşek ${ }^{1}$, Sinem Doğanay ${ }^{2}$, Türkan Günay ${ }^{1}$ \\ ${ }^{1}$ Department of Public Health, Dokuz Eylül University School of Medicine, İzmir, Turkey \\ ${ }^{2}$ Gaziemir Community Health Center, Ministry of Health, İzmir, Turkey
}

Background: The studies have shown that metabolic syndrome (MetS) leads to an increase twice as much in cardiovascular diseases (CVD) and four times as much in diabetes mellitus (DM) prevalence since the second half of the $20^{\text {th }}$ century.

Aims: This study aims to determine and discuss the prevalence of the MetS and co- factors among individuals at the age of 30 and over in Balcova district of İzmir province according to the American National Cholesterol Education Program - Adult Treatment Panel III (NCEP ATP III) and InternationalDiabetes Federation (IDF) criteria. Study Design: Cross-sectional study.

Methods: Data obtained from the Balcova Heart Project in İzmir were used in the study. The dependent variable of the study is MetS existence. The independent variables were socio-demographic characteristics (age, gender, education level, and marital status), self-perceived eco- nomic status, physical activity, smoking status, healthy nutrition and body mass index (BMI).

Results: The prevalence of MetS was $36.9 \%$ according to the diagnostic criteria of IDF, while it was $27.4 \%$ according to ATP III criteria. According to the both criteria, increasing age, low education, poor economic status perception, physical inactivity, and obesity increase the risk of MetS. Apart from the IDF criteria, being female and a current smoker increase the risk of the MetS in the NCEP-ATP III. Conclusion: Compared to educational studies of MetS as of today, which are community and health-oriented studies, it is challenging that the prevalence of MetS was found to be high for both criteria in our study. Therefore, in particular, primary health care doctors must be prompted to protect the public against DM and CVD in particular.

Keywords: IDF criteria, metabolic syndrome, NCEPATP III criteria, prevalence
Mindless eating, overnutrition and physical inactivity, which have recently been on the increase, lead to hormonal and metabolic disorders; therefore, the disease is called metabolic syndrome (MetS). It has been known for a long time that if obesity, gout and stroke coexist, this is caused by mindless eating and overnutrition (1-3). The World Health Organization (WHO) reported that insulin resistance should have at least two concomitant criteria of reduced high density lipoprotein (HDL), high triglycerides (TG), high blood pressure and obesity for the diagnosis of MetS. This definition referred to a major group of patients with a high risk, and made the diagnosis difficult because insulin resistance was a prerequisite (35). However, in the report of American National Cholesterol Education Program - Adult Treatment Panel III (NCEP ATP III), a new definition of the diagnosis of MetS was made, thus making the diagnosis of MetS easier. According to this definition, MetS can be diagnosed in individuals with at least three of the following five parameters: abdominal obesity, glucose intolerance or type 2 diabetes, reduced HDL, high TG and high blood pressure (HT) (6). Today, there is another common 
definition of MetS by the International Diabetes Federation (IDF). Considering this definition, abdominal obesity should have at least two concomitant criteria of disglycemia, reduced HDL, high triglycerides, and high blood pressure for the diagnosis of MetS (7).

Since the second half of the 20th century, there has been an increase in the prevalence of obesity due to physical inactivity and irregular diet, depending on the increase in the urban population, rapid and uncontrolled industrialization, the increasing number of employees in offices and increases in income levels. The studies showed that MetS led to an increase twice as much in CVD and four times as much in diabetes mellitus prevalence (8-11). The prevalence of MetS was almost 30\% in the developed western countries with a rate of $50 \%$ in people aged 50 and over. The Turkish Adult Risk Factor (TARF) study reported that the prevalence of MetS in adults aged 30 and over was $27.0 \%$ in men and $45.2 \%$ in women according to the criteria of NCEP. This study also showed that while the prevalence of MetS in our country was $24.4 \%$ in 1990 , this rate increased to $36.2 \%$ by 2000 (12).

The aim of this study was to determine and discuss the prevalence of MetS and affecting factors among individuals at the age of 30 and over in Balçova District of İzmir province according to NCEP-ATP III and IDF criteria.

\section{MATERIALS AND METHODS}

This is a cross sectional study Dokuz Eylül University Ethical Committee reviewed and approved the study protocol. Verbal and written consents were obtained from all participants.

\section{Study participants}

Data were obtained from Balcova Heart Project in İzmir that lasted from 2007 to 2011. The target population of the project was the residents of Balçova District over 30 years of age without sampling, which was a total of 36,187 people. Every house within the borders of the district was visited at least three times and an invitation was sent to the household of those who could not be reached during visits (13). The study included 12876 participants with all of the essential data related to variables for diagnosing the MetS.

\section{Variables}

The dependent variable of the study was the existence of MetS. The criteria of ATP III and IDF defined by American Heart Association (AHA) were used for the diagnosis of MetS in the study.

According to the ATP III criteria, if the measurement of waist circumference was $\geq 102 \mathrm{~cm}$ in men, and $\geq 88 \mathrm{~cm}$ in women, then they had 'abdominal obesity'. On the other hand, if TG was $\geq 150 \mathrm{mg} / \mathrm{dL}$, then they had 'high TG' and if HDL cholesterol was $<40 \mathrm{mg} / \mathrm{dL}$ in men, and $<50 \mathrm{mg} / \mathrm{dL}$ in women, then they had 'low HDL cholesterol' (Abbott Architecht c16000 auto-analyzer; Abbott Diagnostics, Abbott Park, IL, USA). Hypertension was defined as if the blood pressure was $\geq 130 / 85 \mathrm{mmHg}$ or the participants were under antihypertensive medication. Blood pressure was measured using sphygmomanometer (Erka perfect aneroid, Germany). If fasting blood glucose was $\geq 110 \mathrm{mg} / \mathrm{dL}$ or if the participants stated that they had a diagnosis of DM, then DM was assumed. The presence of at least three of the five criteria abdominal obesity, high TG, reduced HDL cholesterol, HT, and DM achieved the diagnosis of 'MetS' (6).

However, according to IDF criteria, if the waist circumference was $\geq 94 \mathrm{~cm}$ in men, and $\geq 80 \mathrm{~cm}$ in women, then they had abdominal obesity. On the other hand, if TG was $\geq 150 \mathrm{mg} / \mathrm{dL}$, then they had 'high TG' and if HDL cholesterol was $<40 \mathrm{mg}$ / $\mathrm{dL}$ in men, and $<50 \mathrm{mg} / \mathrm{dL}$ in women, then they had 'low HDL cholesterol'. Hypertension was defined as if the blood pressure was $\geq 130 / 85 \mathrm{mmHg}$ or the participants were under antihypertensive medication. If fasting blood glucose was $\geq 100$ $\mathrm{mg} / \mathrm{dL}$ or if the participants stated that they had a diagnosis of $\mathrm{DM}$, then DM was assumed. According to the IDF, the presence of abdominal obesity with at least two of the four criteria high TG, reduced HDL, HT, and DM achieved the diagnosis of 'MetS' (7) (Table 1).

The independent variables were socio-demographic characteristics (age, gender, education level, and marital status), selfperceived economic status, physical activity, smoking status, healthy nutrition and body mass index (BMI).

\section{Age}

In age analysis, we used the following classification: ' 30 39', '40-49', '50-59', '60-69', and 70 years and over.

TABLE 1. Diagnostic criteria of the metabolic syndrome according to NCEP ATP III and IDF

\begin{tabular}{|c|c|c|}
\hline Criteria & NCEP ATP III ${ }^{\mathrm{a}}$ & $\mathrm{IDF}^{\mathrm{b}}$ \\
\hline Waist circumference & $\begin{array}{c}\geq 102 \mathrm{~cm} \text { men } \\
\geq 88 \mathrm{~cm} \text { women }\end{array}$ & $\begin{array}{c}\geq 94 \mathrm{~cm} \text { men } \\
\geq 80 \mathrm{~cm} \text { women }\end{array}$ \\
\hline Triglyceride & $\geq 150 \mathrm{mg} / \mathrm{dL}$ & $\geq 150 \mathrm{mg} / \mathrm{dL}$ \\
\hline High density lipoprotein & $\begin{array}{c}<40 \mathrm{mg} / \mathrm{dL} \text { men } \\
<50 \mathrm{mg} / \mathrm{dL} \text { women }\end{array}$ & $\begin{array}{c}<40 \mathrm{mg} / \mathrm{dL} \text { men } \\
<50 \mathrm{mg} / \mathrm{dL} \text { women }\end{array}$ \\
\hline Blood pressure & $\geq 130 / 85 \mathrm{mmHg}$ & $\geq 130 / 85 \mathrm{mmHg}$ \\
\hline Serum glucose & $\geq 110 \mathrm{mg} / \mathrm{dL}$ & $\geq 100 \mathrm{mg} / \mathrm{dL}$ \\
\hline
\end{tabular}




\section{Educational level}

In educational level analysis, we categorized the participants as: unqualified, primary school graduates (5 years), secondary and high school graduates (6 years), and university and postgraduates. They were divided into two groups, those having a degree and those not having any degree. The group with a degree included the participants who graduated from primary, secondary and high school, as well as those with a bachelor degree and postgraduate education.

\section{Marital status}

The participants were classified as married, single, widowed or divorced. In the analysis, the married participants were considered 'married', while single, widowed, and divorced individuals were denoted 'not married'.

\section{Self-perceived economic status}

The economic status of the participants was categorized as very high, high, average, low and very low. These were also divided into two groups as very high/high and average, and low/very low.

Physical activity: Physical activities such as doing housework, brisk walking and dancing for at least 30 minutes were regarded as 'moderate physical activities'. However, other physical activities like aerobics, cycling, football, weightlifting exercises in fitness centers, and hoeing in the garden for at least 20 minutes leading to panting were assumed to be 'vigorous physical activities'. In order to constitute the data, participants were asked how often they performed these exercises. Those in the moderate physical activity group who declared such as never/more than once in a month/once a week were considered as having 'no physical activity'. Participants who defined the frequency level of the exercises as two and four times a week and five times or more in a week were assumed as those 'having physical activity'. On the other hand, participants in the vigorous physical activity group using the definitions never/less than once in a month were categorized as having 'no physical activity', but those doing the exercises once/ twice a week, three times or more in a week were regarded as 'having physical activity'. Therefore, the presence of any of these two physical activities, which were moderate and vigorous, showed that the participants had 'physical activity'.

\section{Smoking status}

According to the statements of the participants, those smoked at least once a day were considered as 'regular smokers'. These regular smokers were classified as current smokers, and the others smoking rarely/never as well as those who stop smoking were considered as non-smokers.

\section{Healthy nutrition}

The individuals were asked whether they had three meals and three snacks a day regularly. Those having all these meals and snacks regularly were classified as 'well-nourished'. The bread was classified as white and wheat bread according to the types of bread consumed by the individuals. Those consuming wheat bread were considered 'well-nourished'. Participants were asked about the type of cooking oils. They stated four different types such as margarine, butter (solid fats), olive oil and other cooking oils. Those using margarine and butter were assumed as 'having solid fat consumption', while those using olive oil or other liquid fats were regarded as 'having liquid fats'. Also, those consuming liquid fats were considered as 'well-nourished'. Participants who replied 'yes' to the question 'do you eat fruits/vegetables every day?' were also considered 'well-nourished'. To conclude, if the participants had at least three regular consumptions, such as 3 meals plus 3 snacks, wheat bread, liquid fats, vegetables and fruits, they were considered to be 'well-nourished'.

\section{Body mass index}

Body Mass Index was calculated as weight $(\mathrm{kg})$ divided by square of height $\left(\mathrm{m}^{2}\right)$. Obesity was defined as BMI of 30 and above.

\section{Statistical analysis}

SPSS for Windows (version 15.0, SPSS Inc.; Chicago IL, USA) was used for data analysis. The descriptive values were evaluated by using frequency distribution and mean \pm standard deviation (SD). Chi-square test was used for univariate analysis. Logistic regression analysis with multiple variables was made. All of the variables found to be significant were included in the logistic regression analysis model. Also, age was considered a continuous variable in logistic regression analysis. In the reference groups, the categorical variables were being male, having a degree, having a very high/high economic status perception, being married, healthy nutrition, making physical activity, being a non-smoker, and having a BMI under 30.

\section{RESULTS}

The study group consisted of 12876 individuals, 4306 (33.4\%) of whom were male. Considering the educational level of the study group, it was observed that $10.1 \%$ of the participants had no degree, while $45.3 \%$ were primary school graduates with the highest rate in the group of educational level. In terms of the marital status, it was observed that the married participants accounted for $80.9 \%$ of the study group. 
TABLE 2. Distribution of the subjects according to their demographic, socio-economic and health-status characteristics

\begin{tabular}{|c|c|}
\hline Characteristics & $\mathrm{n}(\%)$ \\
\hline \multicolumn{2}{|l|}{ Gender $(n=12876)$} \\
\hline Male & $4306(33.4)$ \\
\hline Female & $8570(66.6)$ \\
\hline \multicolumn{2}{|l|}{ Age group ( $\mathrm{n}=12853$ ) } \\
\hline $30-39$ & $2359(18.4)$ \\
\hline $40-49$ & $3314(25.8)$ \\
\hline $50-59$ & $3363(26.2)$ \\
\hline $60-69$ & $2322(18.1)$ \\
\hline $70+$ & $1495(11.6)$ \\
\hline \multicolumn{2}{|l|}{ Educational level ( $\mathrm{n}=12665)$} \\
\hline Without a degree & $1273(10.1)$ \\
\hline Primary school graduate (5 years) & $5737(45.3)$ \\
\hline Secondary and high school graduate (6 years) & $4101(32.4)$ \\
\hline Bachelor degree or postgraduate & $1554(12.3)$ \\
\hline \multicolumn{2}{|l|}{ Marital status ( $\mathrm{n}=12657)$} \\
\hline Married & $10241(80.9)$ \\
\hline Not married & $2416(19.1)$ \\
\hline \multicolumn{2}{|l|}{ Self-perceived economic status ( $\mathrm{n}=12652$ ) } \\
\hline Very low & $108(0.9)$ \\
\hline Low & $1110(8.8)$ \\
\hline Average & $10189(79.1)$ \\
\hline High & $1229(9.7)$ \\
\hline Very high & $16(0.1)$ \\
\hline \multicolumn{2}{|l|}{ Smoking status $(\mathrm{n}=12695)$} \\
\hline Regular smoker & $3692(29.1)$ \\
\hline Occasional smoker & $400(3.2)$ \\
\hline Ex-smoker & $2678(21.1)$ \\
\hline Non-smoker & $5925(46.7)$ \\
\hline Healthy nutrition (Present) & $1733(13.5)$ \\
\hline Physical activity (Present) & $7931(61.6)$ \\
\hline Coronary heart disease (Present) & $939(7.5)$ \\
\hline Hypertension (Present) & $5727(44.5)$ \\
\hline Diabetes mellitus (Present) & $1446(11.5)$ \\
\hline Stroke (Present) & $244(1.9)$ \\
\hline Body Mass Index (30 and over) & $5039(39.2)$ \\
\hline
\end{tabular}

When the economic status was taken into consideration, it was clear that $79.1 \%$ of the participants defined their economic level as 'fair'. As for the smoking habits and daily vegetable/ fruit consumption, it was seen that $29.1 \%$ of the participants in
TABLE 3. Distribution of subjects according to the prevalence of metabolic syndrome

\begin{tabular}{lcc}
\hline & \multicolumn{2}{c}{ Prevalence of Metabolic syndrome } \\
\cline { 2 - 3 } Characteristic & $\begin{array}{c}\mathrm{IDF}^{\mathrm{b}} \\
\mathrm{n}(\%)\end{array}$ & $\begin{array}{c}\text { ATP III } \\
\mathrm{n}(\%)\end{array}$ \\
\hline Metabolic syndrome (Present) & $4753(36.9)$ & $3524(27.4)$ \\
Waist circumference (High) & $8189(63.6)$ & $4444(34.5)$ \\
Level of serum triglyceride (High) & $4411(34.3)$ & $4411(34.3)$ \\
Level of serum glucose (High) & $2801(21.8)$ & $1863(14.5)$ \\
Blood pressure (High) & $6078(47.2)$ & $6078(47.2)$ \\
High density lipoprotein (Low) & $5437(42.2)$ & $5437(42.2)$ \\
\hline $\begin{array}{l}{ }^{a} \text { American National Cholesterol Education Program-Adult Treatment Panel III } \\
\text { bInternational Diabetes Federation }\end{array}$ & \multicolumn{2}{l}{}
\end{tabular}

our study were current smokers, and $55.2 \%$ of them consumed four or less portions of fruit. It was determined that $61.6 \%$ of the participants performed regular physical activity and $39.2 \%$ of them had a BMI of $30 \mathrm{~kg} / \mathrm{m}^{2}$ and over. In the whole group, $7.5 \%$ of the participants had CHD, $44.5 \%$ of them had hypertension, $11.5 \%$ had diabetes mellitus and $1.9 \%$ had a history of stroke (Table 2).

It was found that the prevalence of MetS in all of the study groups was $36.9 \%$ according to the diagnostic criteria of IDF; however, this prevalence was $27.4 \%$ according to the diagnostic criteria of NCEP-ATP III. The diagnostic criteria of IDF and NCEP-ATP III, which are high serum triglycerides, high blood pressure and reduced HDL cholesterol were $34.3 \%, 47.2 \%$ and $42.2 \%$, respectively. According to the different criteria of the two foundations, it was revealed that the waist circumference of the study group was $63.6 \%$ according to the IDF, and was $34.5 \%$ according to the NCEP-ATP III. It was also observed that, according to the IDF criteria, $21.8 \%$ of the individuals had high levels of serum fasting glucose compared to the individuals according to the ATP III criteria which showed $14.5 \%$ (Table 3).

When considering the prevalence of the MetS in terms of gender, it was determined that $38.5 \%$ of females and $33.7 \%$ of males had MetS according to the criteria of IDF. However, in accordance with ATP III criteria, $29.6 \%$ of females and $22.9 \%$ of males had MetS, and in the evaluation of both criteria, it was evident that the prevalence of MetS increased with age (Table 4). Also, the effect of independent variables on the prevalence of the MetS according to both criteria is given in table 5 with the analysis of univariate and multiple variables. In terms of the univariate analysis, all independent variables had a significant effect on the prevalence of MetS defined according to both criteria.

According to both criteria, increasing age, low education, poor economic status, physical inactivity, and obesity increase 
TABLE 4. Prevalence of the metabolic syndrome according to gender and age

\begin{tabular}{lcc}
\hline & \multicolumn{2}{l}{ Prevalence of Metabolic syndrome } \\
\cline { 2 - 3 } Characteristic & $\begin{array}{c}\text { IDF }^{\mathrm{b}} \\
\mathrm{n}(\%)\end{array}$ & $\begin{array}{c}\text { ATP III }^{\mathrm{a}} \\
\mathrm{n}(\%)\end{array}$ \\
\hline Gender & & \\
Female & $3300(38.5)$ & $2536(29.6)$ \\
Male & $1453(33.7)$ & $988(22.9)$ \\
Age groups & & \\
$30-39$ & $355(15.0)$ & $187(7.9)$ \\
$40-49$ & $905(27.3)$ & $583(17.6)$ \\
$50-59$ & $1438(42.8)$ & $1079(32.1)$ \\
$60-69$ & $1251(53.9)$ & $1016(43.8)$ \\
$70+$ & $800(53.5)$ & $658(44.0)$ \\
\hline
\end{tabular}

${ }^{\mathrm{a} A m e r i c a n ~ N a t i o n a l ~ C h o l e s t e r o l ~ E d u c a t i o n ~ P r o g r a m-~ A d u l t ~ T r e a t m e n t ~ P a n e l ~ I I I ~}$ 'International Diabetes Federation

the risk of MetS. Apart from the IDF criteria, being a female and a current smoker increases the risk of the MetS in the NCEP-ATP III (Table 5).

\section{DISCUSSION}

There have been many studies related to the prevalence of MetS in recent years. In some of these studies, the criteria of NCEP ATP III were used, while in others, the guidelines of IDF were used. Besides, in many studies like ours, two definitions of MetS were used and compared, as were the criteria of NCEP ATP III and IDF. When we consider the studies performed in European countries, the multicenter cross-sectional study in Greece made in 2003 and 2004 involving 9669 participants aged 18 and over showed the prevalence of MetS was $24.5 \%$ for NCEP ATP III criteria, but $43.4 \%$ for IDF criteria (14). In another study carried out in Portugal including 886 women and 547 men aged between 18 and 92, it was reported that the prevalence of MetS was $24.0 \%$ according to the criteria of 18-NCEP ATP III, while it was $41.9 \%$ for IDF criteria (15). On the other hand, the study of GEMCAS conducted in Germany involving 35869 individuals aged between 18 and 99 concluded that the prevalence of MetS was $19.8 \%$ for NCEP ATP III, while this prevalence was $32.4 \%$ in the criteria of IDF (16). The HUNT-2 study, performed in Norway from 1995 to 1997 with 10206 participants aged between 20 and 89 , measured the prevalence and reported that it was $29.6 \%$ according to the criteria of IDF, but for NCEP ATP III it was $25.9 \%$ (17). Considering one of the other studies undertaken in Romania, a different method was used to measure the prevalence of MetS among 1176 inpatients, $49.7 \%$ of whom were males and had admission to 12 cardiology departments in the country. Ultimately, it was found that the prevalence was $40.6 \%$ in NCEP ATP III criteria and $44.2 \%$ in IDF criteria (18). However, when analyzing the studies conducted in Asian countries, the study of India involving 2318 individuals showed that according to the definition of NCEP ATP III the prevalence was $40.3 \%$ while it was $34.9 \%$ for the criteria of IDF (19). In another study performed in Shanghai district of China including 2477 men and 3107 women whose ages ranged from 20 to 79, it was reported that men had a prevalence of MetS with a rate of $22.7 \%$ and women with $25.0 \%$ in terms of NCEP ATP III criteria; on the other hand, according to IDF guidelines, the prevalence was found to be $15.9 \%$ in men and $19.2 \%$ in women (20). In another multicenter public study conducted in Philippines with 4753 participants aged over 20 , the prevalence was reported to be $11.9 \%$ for ATP III, and $14.5 \%$ for IDF (21). Also, the study performed in the Kuala Lumpur district of Malaysia involving 1494 individuals evaluated according to ATP III and IDF criteria found that the prevalence was $41.4 \%$ and $38.2 \%$, respectively (22). According to a study conducted in Talca district of Chile, one of the South American countries involving 1007 participants aged between 18 and 74 , the prevalence was $29.5 \%$ for the definition of ATP III and $36.4 \%$ for IDF (23). Furthermore, depending on ENSANUT research in 2006, another multicenter study in Mexico including urban and rural areas consisting of 45446 individuals whose ages were over 20 found out that MetS prevalence was $36.8 \%$ in terms of ATP III criteria, but $49.8 \%$ in IDF guidelines (24). In one of the other studies in the Seychelles, which is situated in an African Continent which involved 1255 individuals between 25 and 64 years old, the prevalence of MetS was measured to be $32.2 \%$ in women and $24.0 \%$ in men according to ATP III criteria, while these rates were $35.4 \%$ and $25.1 \%$, respectively, in terms of IDF definition (25).

As a result, in all studies, the prevalence of MetS was found to be quite high for both definitions. In our study, it was observed that the prevalence of MetS was $27.4 \%$ depending on ATP III criteria; however, it was $36.9 \%$ depending on IDF. Therefore, the result obtained from our study is consistent with the results of other studies. On the other hand, it can be inferred from the aforementioned study in Romania including inpatients from 12 cardiology centers in the country that the reason for the higher prevalence in comparison to our study and the others according to both criteria is that the study is not community oriented.

It was also stated in this study that the abdominal obesity was high particularly among the cardiac patients (18). It is possible to conclude that in some South and Central American 
TABLE 5. The effect of independent variables on the prevalence of the metabolic syndrome according to both criteria

\begin{tabular}{|c|c|c|c|c|c|c|c|c|}
\hline \multirow[b]{3}{*}{ Characteristic } & \multicolumn{4}{|c|}{$\mathrm{IDF}^{\mathrm{b}}$} & \multicolumn{4}{|c|}{$\mathrm{ATP}_{\text {III }}^{\mathrm{a}}$} \\
\hline & \multicolumn{2}{|c|}{ Univariate analyses } & \multicolumn{2}{|c|}{ Multivariate analyses } & \multicolumn{2}{|c|}{ Univariate analyses } & \multicolumn{2}{|c|}{ Multivariate analyses } \\
\hline & $\%$ & $\mathrm{p}$ & $\mathrm{OR}^{\mathrm{c}}(95 \% \mathrm{CId})$ & $\mathrm{p}$ & $\%$ & $\mathrm{p}$ & $\mathrm{OR}^{\mathrm{c}}(95 \% \mathrm{CId})$ & $\mathrm{p}$ \\
\hline Age & - & $<0.001$ & $1.043(1.039-1.047)$ & $<0.001$ & - & $<0.001$ & $1.049(1.045-1.054)$ & $<0.001$ \\
\hline \multicolumn{9}{|l|}{ Gender } \\
\hline Male & 33.7 & $<0.001$ & 1.000 & 0.657 & 29.6 & & 1.000 & 0.005 \\
\hline Female & 38.5 & & $1.021(0.931-1.120)$ & & 22.9 & $<0.001$ & $1.160(1.047-1.286)$ & \\
\hline \multicolumn{9}{|l|}{ Educational level } \\
\hline With a degree & 34.6 & $<0.001$ & 1.000 & 0.001 & 25.0 & $<0.001$ & 1.000 & $<0.001$ \\
\hline Without a degree & 57.8 & & $1.260(1.096-1.450)$ & & 48.6 & & $1.276(1.108-1.470)$ & \\
\hline \multicolumn{9}{|c|}{ Economic status perception } \\
\hline Very good/good & 30.9 & & 1.000 & 0.049 & 21.7 & & 1.000 & 0.034 \\
\hline Fair & 37.5 & $<0.001$ & $1.155(1.001-1.333)$ & 0.026 & 27.6 & $<0.001$ & $1.189(1.013-1.789)$ & $<0.001$ \\
\hline Worst/bad & 39.1 & & $1.241(1.026-1.501)$ & & 31.4 & & $1.461(1.187-1.798)$ & \\
\hline \multicolumn{9}{|l|}{ Marital status } \\
\hline Married & 35.2 & $<0.001$ & 1.000 & 0.695 & 25.6 & $<0.001$ & 1.000 & 0.670 \\
\hline Not Married & 44.4 & & $1.022(0.916-1.141)$ & & 35.2 & & $0.975(0.867-1.096)$ & \\
\hline \multicolumn{9}{|l|}{ Smoking status } \\
\hline Non-smoker & 40.3 & $<0.001$ & 1.000 & 0.146 & 30.4 & $<0.001$ & 1.000 & 0.035 \\
\hline Smoker(currently) & 28.9 & & $1.074(0.975-1.184)$ & & 20.1 & & $1.123(1.008-1.252)$ & \\
\hline \multicolumn{9}{|l|}{ Physical activity } \\
\hline Yes & 33.6 & $<0.001$ & 1.000 & 0.003 & 23.7 & $<0.001$ & 1.000 & $<0.001$ \\
\hline No & 42.3 & & $1.137(1.044-1.238)$ & & 33.3 & & $1.232(1.124-1.350)$ & \\
\hline \multicolumn{9}{|l|}{ Body mass index } \\
\hline Under 30 & 21.6 & $<0.001$ & 1.000 & $<0.001$ & 13.7 & $<0.001$ & 1.000 & $<0.001$ \\
\hline 30 and over & 60.6 & & $5.054(4.649-5.494)$ & & 48.6 & & $5.410(4.936-5.930)$ & \\
\hline \multicolumn{9}{|l|}{ Healthy nutrition } \\
\hline Yes & 37.3 & 0.734 & 1.000 & 0.639 & 27.9 & & 1.000 & 0.792 \\
\hline No & 36.9 & & $1.029(0.913-1.159)$ & & 27.3 & 0.574 & $1.018(0.894-1.158)$ & \\
\hline
\end{tabular}

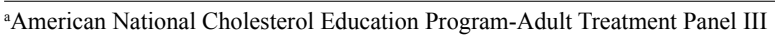

'International Diabetes Federation

'Odds Ratio

${ }^{\mathrm{d}}$ Confidence interval

countries and Asian countries, the cause of a higher prevalence of MetS than those in European countries is that these countries have different eating habits and therefore lead to abdominal obesity, which is an important factor for MetS $(19,22)$.

Except for two studies made in India and Malaysia, the prevalence of MetS was found to be higher in both genders for IDF criteria than those for ATP III criteria in all the researches which were similar to our study $(19,22)$. In another study conducted in Malaysia, it was reported that the prevalence of MetS was measured to be higher, as in our study and others according to the IDF definition compared to the definition of NCEP ATP III; this prevalence was also high in the analyses depending on ethnic groups (26). This condition is caused by the fact that the waist circumference, which is the central obesity criterion in IDF definition, is $\geq 94 \mathrm{~cm}$ in males and $\geq 80$ $\mathrm{cm}$ in females for European region; this waist circumference varies among ethnic groups and regions and is lower for both genders compared to the NCEP ATP III definition. NCEP ATP III defined no regional difference and the waist circumference for central obesity is $\geq 102 \mathrm{~cm}$ in males and $\geq 88 \mathrm{~cm}$ in females according to NCEP ATP III.

Similar to other studies, it was observed in our study that the prevalence of MetS was higher in women than in men in terms of both criteria. However, as both genders grew older, the prevalence also increased. This may be caused by a more sedentary lifestyle and lack of physical activity as the indi- 
viduals become older. Furthermore, as observed in other studies, the low education level of our study group had a negative effect on the prevalence of MetS. (14-29).

In conclusion, compared with the community and healthoriented studies for MetS today, it is challenging that the prevalence of MetS was found to be high in our study achieved in the Balçova District of İzmir according to the IDF and ATPIII criteria. Therefore, the education of society must be emphasized to protect the community against DM and CVD in particular. People must be educated about nutrition habits, and obesity must be under strict control. Primary healthcare doctors who will be the first step to take part in these educations and make the community focus on obesity, DM, HT, and MetS are very important.

Ethics Committee Approval: Ethics committee approval was received for this study from the ethics committee of Dokuz Eylül University School of Medicine (22 November 2007, Meeting number: 01/25/2007).

Informed Consent: Written informed consent was obtained from individuals who participated in this study.

Peer-review: Externally peer-reviewed.

Author contributions: Concept - A.S., S.D.,T.G.; Design - A.S., H.Ş., S.D.; Supervision - A.S., H.Ş., T.G.; Resource A.S., H.Ş., T.G.; Materials - A.S., H.Ş., S.D.; Data Collection and/or Processing A.S., H.Ş., S.D.; Analysis and/or Interpretation - A.S., H.Ş., S.D.; Literature Search - A.S., H.Ş., T.G.; Writing A.S., H.Ş., T.G.; Critical Reviews - A.S., H.Ş., T.G.

Conflict of Interest: The authors state no conflict of interest.

Financial Disclosure: This study was supported jointly by Balcova Municipality and Dokuz Eylül University Research Fund (Grant no: 2007161).

\section{REFERENCES}

1. Reaven GM. Banting lecture 1988. Role of insulin resistance in human disease. Diabetes 1988;37:1595-607. [CrossRef]

2. Reaven GM. Role of insulin resistance in human disease (syndrome X): an expanded definition. Annu Rev Med 1993;44:12131. [CrossRef]

3. Gedik O. Metabolik sendromun tanımı ve tanı kriterleri. Klinik Aktüel Tıp, 2005; Metabolik sendrom özel saylsı, 5:1-5.

4. Alberti KG, Zimmet PZ. Provisional report of a WHO consultation Definition, diagnosis and classification of diabetes mellitus and its complications, part 1: diagnosis. Diabet Med 1998;15:539-53. [CrossRef]
5. Balkau B, Charles MA. Comment on the provisional report from the WHO consultation. European group for the study of insulin resistance (EGIR). Diabet Med 1999;16:442-3. [CrossRef]

6. National Cholesterol Education Program (NCEP). Expert panel on detection, evaluation and treatment of high blood cholesterol in adults (Adult Treatment Panel III). Third Report of the National Cholesterol Education Program (NCEP) expert panel on detection, evaluation and treatment of high blood cholesterol in adults (Adult Treatment Panel III) final report. Circulation 2002;106:3142-421.

7. The IDF Consensus Worldwide Definition of the Metabolic Syndrome. Internatioanl Diabetes Federation 2006 Available from: http://www.idf.org/webdata/docs/IDF_Meta_def_final.pdf

8. Soysal A, Demiral Y, Soysal D, Uçku R, Köseoğlu M, Aksakoğlu G. The prevalence of metabolic syndrome among young adults in Izmir, Turkey. Anadolu Kardiyol Derg 2005;5:196-201.

9. Santos AC, Ebrahim S, Barros H. Gender, socio-economic status and metabolic syndrome in middle-aged and old adults. BMC Public Health 2008;8:62. [CrossRef]

10. Hoang CK, Ghandeari H, Lopez VA, Barboza MG, Wong ND. Global coronary heart disease risk assessment of individuals with the metabolic syndrome in the U.S. Diabetes Care 2008;31:1405-9. [CrossRef]

11. Tanyolaç S, Çıkım AS, Azezli AD, Orhan Y. Correlation between educational status and cardiovascular risk factors in an overweight and obese Turkish female population. Anadolu Kardiol Derg 2008;8:336-41.

12. Onat A, Sarısoy V. Halkımızda koroner hastalığın baş suçlusu metabolik sendrom: sıklığı, unsurları, koroner risk ile ilişkisi ve yüksek risk kriterleri. Türk Kardiyoloji Dern Arş 2002;30:8-15.

13. Ergör G, Soysal A, Sözmen K, Ünal B, Uçku R, Kılıç B, et al. Balçova Heart Study: rationale and methodology of Turkish cohort. Int J Public Health 2012;535-42. [CrossRef]

14. Athyros VG, Ganotakis ES, Bathianaki M, Mönedas I, Goudevenos IA, Papageorgiou AA, et al. Awareness, treatment and control of the metabolic syndrome and its components: A Multicentre Greek Study. Hellenic J Cardiol 2005;46:380-6.

15. Santos AC, Barros H. Impact of metabolic syndrome definitions on prevalence estimates: A study in a Portuguese Community. Diab Vasc Dis Res 2007;4:320-7. [CrossRef]

16. Moebus S, Hanisch JU, Aidelsburger P, Bramlage P, Wasem J, Jöcke KH. Impact of the metabolic syndrome in primary healthcare: The German metabolic and cardiovascular risk project (GEMCAS). Cardiovasc Diabetol 2007;6:22. [CrossRef]

17. Hildrum B, Mykletun A, Hole T, Midthjell K, Dahl AA. Agespecific prevalence of the metabolic syndrome defined by the national cholesterol education program: The Norwegian HUNT 2 Study. BMC Public Health 2007;7:220. [CrossRef]

18. Matei C, Pop I, Jurgut R, Suceveanu M, Predescu D, Nechita E, et al. ROmanian multicentric study of the prevalence of MEtabolic Syndrome-ROMES. Hellenic J Cardiol 2008;49:303-9.

19. Kanjilal S, Shanker J, Rao V, Khadrinarasimhaih N, Mukherjee M, Iyengar S, et al. Prevalence and component Analysis of Metabolic 
Syndrome: An Indian atherosclerosis research study perspective. Vasc Health Risk Manag 2008;4:189-97. [CrossRef]

20. Xiang Y, Huang G, Zhou W, Che Z, Zhou P, Zhou Z. Prevalence of metabolic syndrome (MetS) in Chinese subjects gradually increased with impaired glucose homeostasis: a multicenter, clinical based, cross-sectional study. BMC Public Health 2012. [CrossRef]

21. Morales D, Punzalan EF, Pacheco E, Sy RG. Metabolic Syndrome in the Philippine General Populatin: Prevalence and risk for atherosclerotic cardiovascular disease and diabetes mellitus. Diabetes Vasc Dis Res 2008;5:36-43. [CrossRef]

22. Moy FM, Bulgiba A. The Modified NCEP ATP III Criteria maybe better than the IDF criteria in diagnostic metabolic syndrome among Malays in Kuala Lumpur. BMC Public Health 2010;10:678. [CrossRef]

23. Mujika V, Leiva A, Icaza G, Diaz N, Arredonto M, Carrasco R, et al. Evaluation of metabolic syndrome in adults of Talca City, Chile. Nutr J 2008;7-14. [CrossRef]

24. Rojas R, Salinas C, Corana A, Leavy T, Nut L, Rauda J, et al. Metabolic Syndrome in Mexican Adults. Results from the Na- tional Health and Nutrition Survey 2006. Salud Publica Mex 2010; 52(Suppl 1):511-8. [CrossRef]

25. Kelliny C, William J, Riesen W, Pascaud F, Bovet P. Metabolic Syndrome According to different definitions in a rapidly developing country of the African Region. Cardiovasc Diabetol 2008;7:27. [CrossRef]

26. Ramli AS, Daher A, Ashikin MNK, Nasir N, Ng KK, Miskan $\mathrm{M}$, et al. JIS Defination identified more Malaysian adults with metabolic syndrome compared to the NCEP-ATP III and IDF Criteria. Biomed Res Int 2013;1-10. [CrossRef]

27. Ivezic-Lalic D, Markoviç BB, Kranjceviç K, Kern J, Vrdoljak D, Vucak J. Med Sci Monit 2013;19:571-8. [CrossRef]

28. Cai H, Huang J, Xu G, Yang Z, Liu M, Mi Y, et al. Prevalence and determinants of metabolic syndrome among women in Chinese Rural Areas. PloS One 2012; 7:e36936. [CrossRef]

29. Shafique K, Mirza SS, Mughal MK, Arain ZI, Khan NA, Tareen MF, et al. Water-Pipe smoking and metabolic syndrome: A Population-Based Study. PLoS One 2012;7:e39734. [CrossRef] 